\title{
APPRAISAL OF LANDSLIDES DUE TO RAINFALL
}

\author{
Alfrendo Satyanaga Nio \\ Geotechnics Laboratory Staff, School of Civil and Environmental Engineering, \\ Nanyang Technological University, Singapore. \\ e-mail: maredoez@yahoo.com
}

\begin{abstract}
ABSTRAK
Makalah ini menjelaskan analisa pengaruh hujan terhadap kestabilan lereng melalui beberapa simulasi dengan menggunakan software geoteknik. Keruntuhan lereng bisanya terjadi pada tanah residual yang terletak di daerah yang mengalami musim hujan yang berkepanjangan. Dari hasil simulasi yang dilakukan, dapat disimpulkan bahwa kestabilan lereng dipengaruhi oleh 2 faktor yang sangat penting, yaitu: curah hujan dan geometri dari lereng tersebut. Hasil analisis menggambarkan hubungan antara 2 faktor penting tersebut dan kestabilan dari lereng, berikut dengan kesimpulannya. Perbandingan dengan data dari hasil penelitian yang lain juga dilampirkan dalam makalah ini.
\end{abstract}

Kata kunci: Stabilitas lereng, Matric suction, Curah Hujan, Tanah Residual, Keruntuhan lereng.

\begin{abstract}
This paper describes an investigation into rainfall-induced slope stability via a parametric study. Landslides usually occur in residual soil slopes and exposed to prolonged and/or heavy rainfall. The parametric study conducted investigates the effect of two of the important parameters affecting the slope stability, slope geometry and rainfall loading. The results show that there are some correlations between the two factors and slope stability, along with other conclusions. Comparisons have also been made to other results obtained by other researchers
\end{abstract}

Keywords: Slope stability, Matric suction, Rainfall, Residual soil, Slope failure.

\section{INTRODUCTION}

Rainfall-induced slope failures are shallow failures (typically $1 \mathrm{~m}$ to $1.5 \mathrm{~m}$ deep) that occur due to prolonged and/or heavy rainfall. This type of slope failure often occurs in residual soils in climates that allow prolonged and/or heavy rainfall (Fourie, 1996). Many researchers (e.g. Lumb, 1975; Rahardjo, 2000) have concluded that these failures can be attributed to the infiltration of rainwater into the slope as the most important factor contributing to rainfall-induced slope failures.

The objective of the project is to conduct a parametric study to assess the effect of various parameters in rainfall-induced slope failures. The parameters studied were the slope geometry (case A) and the rainfall applied (case B). 


\section{METHODOLOGY}

The methodology involves three steps (i) selecting appropriate values for the parameters used in the analysis, (ii) seepage analysis and (iii) slope stability analysis. This methodology is similar to what has been done (Rahardjo et al., 2006).

\subsection{Selecting appropriate values for the parameters used in analysis}

For Case A, the soil chosen comes from a Jurong Sedimentary Formation. The soil properties were taken as shown in the Table 1 .

Table 1. Soil Properties for Case A.

\begin{tabular}{cc}
\hline Water Content (\%) & 30 \\
\hline Liquid Limit (\%) & 65 \\
Plastic Limit (\%) & 35 \\
Plasticity Index (\%) & 30 \\
Total Density (Mg/m3) & 2.1 \\
Sand (\%) & 5 \\
Silt (\%) & 25 \\
\hline Clay (\%) & 70 \\
\hline
\end{tabular}

The shear strength parameters of the soils used for Case A are $c^{\prime}=5 \mathrm{kPa}$, effective angle of internal friction, $\phi^{\prime}=26^{\circ}$, rate of increase in shear strength caused by matric suction, $\phi^{b}=11^{\circ}$. The shear strength parameters $\phi^{b}$ was later found out to be slightly low, whereby the typical value for such a soil should be somewhere around $16^{\circ}$ to $19^{\circ}$. However, due to time constraints, a review of the analysis was unable to be carried out.

Meanwhile, the Soil Water Characteristic Curve (SWCC) and the permeability function used were derived according to Fredlund and Xing (1994) from the grains size analysis. The saturated permeability is taken as $1 \times 10^{-4}$, which is a rather high value. The derived permeability function is shown in Figure 1.

The rainfall intensity of $2.2 \times 10^{-5} \mathrm{~m} / \mathrm{s}$ was applied in this case for 4 hours. The slope geometry was varied by changing the angle of the slope, $\alpha$. The angles used in the analysis ranged from $26.6^{\circ}$ to $42.0^{\circ}$.

For Case B, there are two layers of soils from a Bukit Timah Granitic Formation, the top layer being a medium stiff silty sand layer with the bottom layer being a hard silty sand layer. 


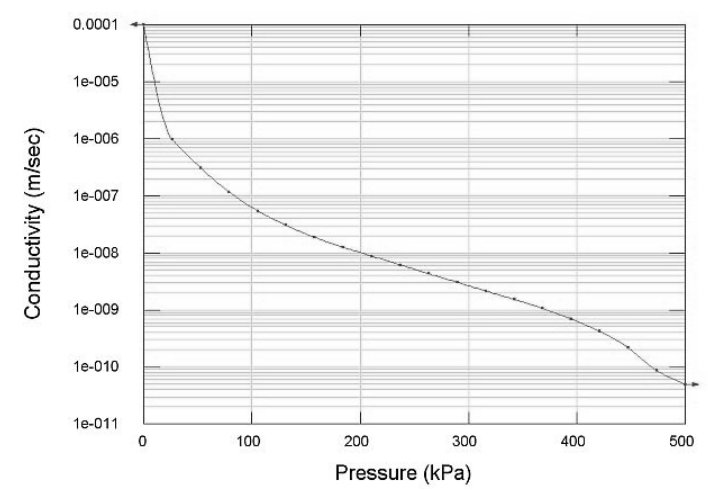

Figure 1. Permeability Function for Case A.

The shear strength parameters for the top layer are $c^{\prime}=5 \mathrm{kPa}$, effective angle of internal friction, $\phi^{\prime}=30^{\circ}$, rate of increase in shear strength caused by matric suction, $\phi^{b}=$ $17^{\circ}$. This is taken from experiment conducted in NTU's Geotechnics Laboratory (Chong, 2007)

Meanwhile, the bottom layer's shear strength parameters are $c^{\prime}=8 \mathrm{kPa}$, effective angle of internal friction, $\phi^{\prime}=33^{\circ}$, rate of increase in shear strength caused by matric suction, $\phi^{b}=21.5^{\circ}$ (Khonsavanh, 2007).

The SWCC functions are taken from experiment conducted by Chong and Khonsavanh for the top and bottom layers respectively. From the SWCC, the permeability function is derived for the two layers of soils.

There is no experimental measurement for the saturated permeability of the soils, and thus they are taken to be $2 \times 10^{-5} \mathrm{~m} / \mathrm{s}$ and $2 \times 10^{-7} \mathrm{~m} / \mathrm{s}$ respectively, which are reasonable values for these soils. Figure 2 shows the permeability function for the top layer while Figure 3 shows the permeability function for the bottom layer.

Table 2. Rainfall loading for Case $B$.

\begin{tabular}{ccc}
\hline Total (mm) & Duration (h) & Intensity (m/s) \\
\hline 533.2 & 24 & $6.17 \times 10^{-6}$ \\
\hline 376.7 & 12 & $8.72 \times 10^{-6}$ \\
\hline 281.9 & 6 & $1.31 \times 10^{-5}$ \\
\hline 151.4 & 3 & $1.40 \times 10^{-5}$ \\
\hline
\end{tabular}

The slope angle, $\alpha$, is $26^{\circ}$, with a slope height of $11.5 \mathrm{~m}$. The top layer thickness is $5 \mathrm{~m}$. Meanwhile, the water table is defined according to field measurement. There are four different rainfall intensities applied to the slope in Case B, shown in table 2. These rainfalls 
are rainfalls with a 100-yr return period obtained from Singapore's National Environmental Agency (NEA).

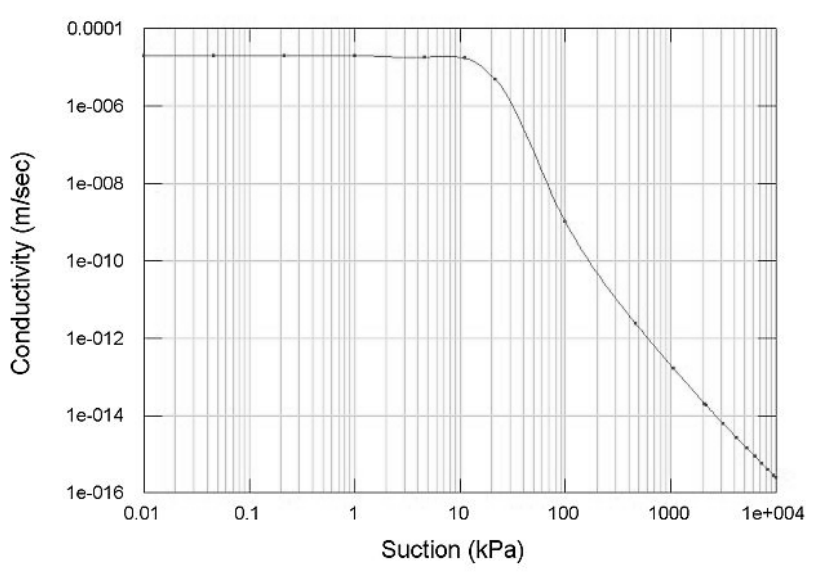

Figure 2. Permeability Function for Case B, Top Layer.

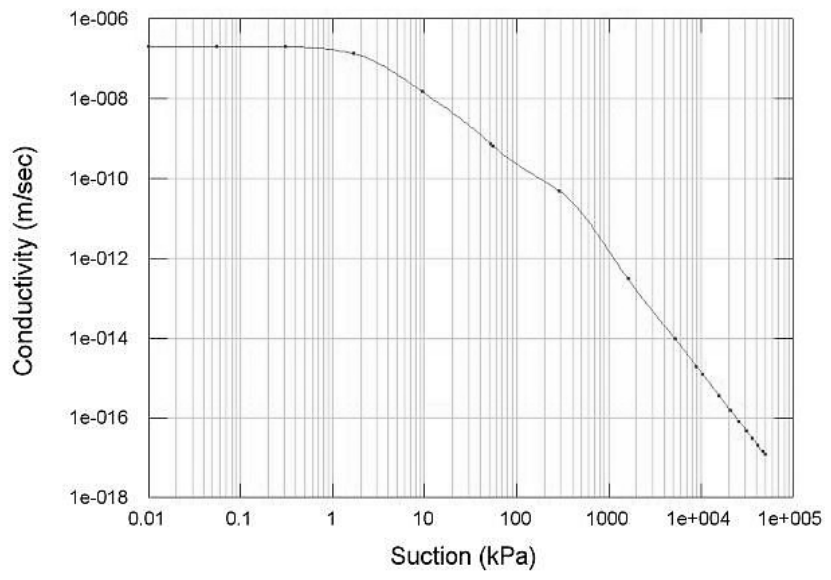

Figure 3. Permeability Function for Case B, Bottom Layer.

\subsection{Seepage Analysis}

The analysis for the rainfall-induced slope stability is conducted using the programme Geo-Slope 2004. In the program, there are two components used in this project, Seep/W for seepage analysis and Slope/W for slope stability analysis.

In the seepage analysis, the infiltration of the rainfall into the soil is modelled, yielding the pore-water pressure distribution throughout the cross-section of the slope at any specified time. The pore-water pressure can then be used in the slope stability analysis to obtain the factor of safety of the slope at any specified time. 
The boundary conditions specified for Case A and Case B in the seepage analysis are similar, with a slight difference. In both cases, a boundary flux, $q$, equal to the rainfall intensity is applied to the top surface of the slope. The nodal flux, $Q$, is applied to the bottom of the slope in both cases to indicate that no flow is allowed at this boundary.

Equal total heads, $H$, is applied to the sides of the slope in Case A. However, $H$ is only applied on the sides of the slope below the water table in Case B, with $Q$ being applied to the sides of the slope above the water table.

The limit on negative pressure was specified to be the maximum suction present in the ground hydrostatically, prior to the rainfall. This limit should not be less than $-75 \mathrm{kPa}$, which is based on field measurements around Singapore (Rahardjo, 2000).

\subsection{Slope Stability Analysis}

For the slope stability analysis, both the simplified Bishop and Morgenstern-Price (with half-sine function) methods were used. The factors of safety obtained from the two methods are very close (with difference of not more than 0.003 ) and for recording purpose, the results from the more rigorous Morgenstern-Price method were recorded.

\section{RESULTS}

The results will be divided into two parts, one pertaining to the effect of slope geometry (Case A), with the other pertaining to the effect of rainfall (Case B). It should be noted that all other parameters were kept constant when the investigated parameter, slope geometry for Case A and rainfall for Case B, during the numerical modelling.

\subsection{Effect of Slope Geometry}

The results for Case A is summarised by Figure 4, which shows the variation of factor of safety against time for 5 slopes with different slope angles. From the graph, it can be seen that the variation of factor safety with time is similar for all the slopes, whereby the factor of safety decreases and reach minimum factor of safety at the end of the rain before rising again. This indicates that the permeability of the soil is rather high as immediately after the rain stops, the factor of safety bounce back. However, it should be noted that the factor of safety does not seem to rise back to the original factor of safety before the rain.

Another interesting phenomenon is that the steeper the slope, the smaller the factor of safety, i.e. the possibility of failure to occur is larger for steeper slopes. This is highlighted by the modelling result which suggests slope with $42^{\circ}$ is expected to fail at the end of the 
rain, while the other gentler slopes are not expected to fail. This observation is consistent with what was reported (Rahardjo et al., 2006).

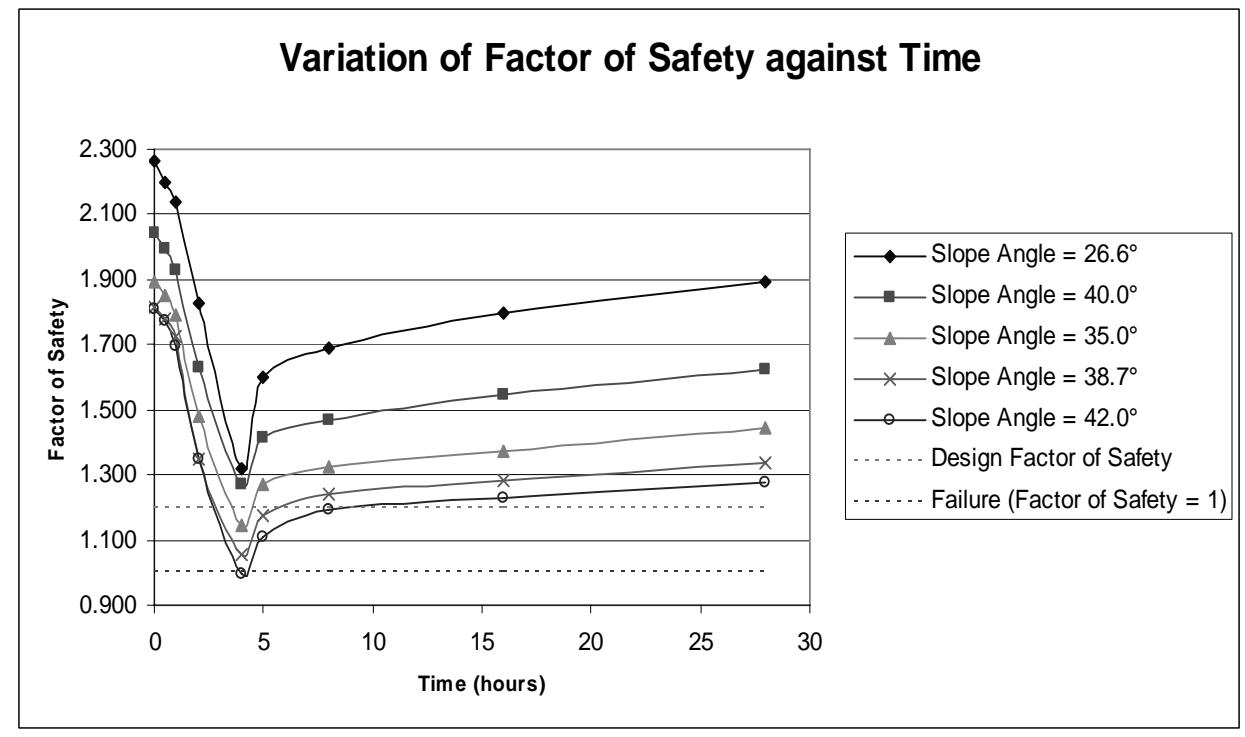

Figure 4. Plot of Factor of safety against Time for Case A.

\subsection{Effect of Rainfall}

The results for Case B is summarised in Figure 8, which shows the variation of factor of safety against time for a slope exposed to four different rainfall patterns. From the results presented, there are three conclusions that can be drawn.

Firstly, the more intense the rainfall, the faster the factor of safety drops. This can be seen as the gradient of the graph for more intense rainfall is steeper than for less intense rainfall.

This can be attributed to the speed in which rainwater percolates into the soil. It is expected that more rainwater percolates and it percolates faster in more intense rainfall. This observation is consistent with what was reported (Rahardjo et al., 2006).

Secondly, the drop in factor of safety is observed to be larger when the rainfall has bigger volume. This can be attributed to the amount of water that enters the soil during and at the end of the rain. The more water enters, the less the matric suction in the soil will be. This will result in lower strength of the soil and lower factor of safety of the slope.

Lastly, for all the rainfalls, the factor of safety seems to rise back to a common value of approximately 1.70 , regardless of the exposure to different rainfall.

This may indicate that the factor of safety of the slope will return to a value, provided that no more rainfall occurs. This value does not seem to depend on the rainfall but the physical condition of the slope itself, instead. 


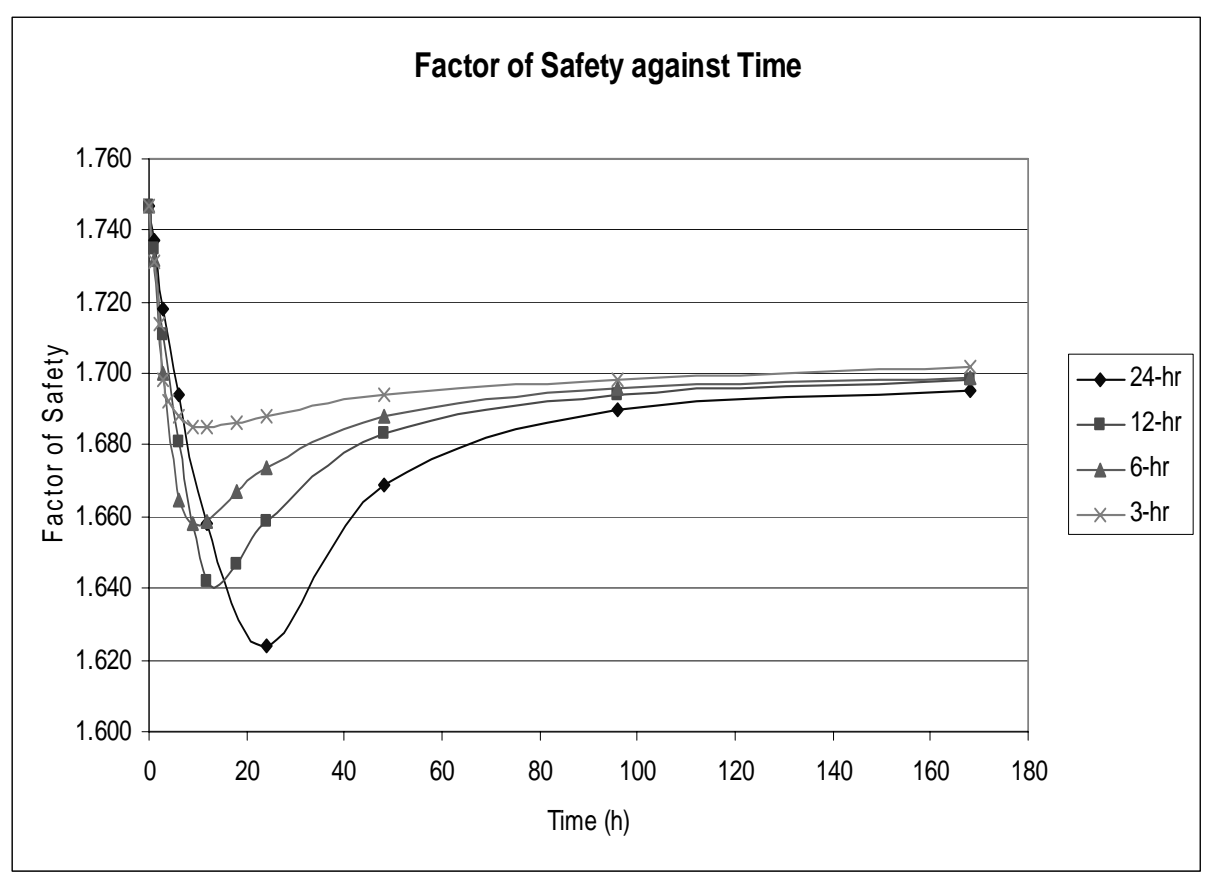

Figure 5. Plot of Factor of safety against Time for Case B.

\section{CONCLUSION}

The parametric study was aimed to investigate the effect of several important factors affecting rainfall-induced slope stability problems. In the end, two factors were investigated, slope geometry and rainfall loading.

Using the numerical modelling programme, Geo-slope 2004, the author was able to observe some effects of the two parameters being tested. It is observed that the steeper the angle the slope, the lower the factor of safety of safety.

Meanwhile, both the rainfall intensity and volume have pronounced effects to the slope stability. When the rainfall is more intense, the factor of safety drops faster and when the rainfall is larger (i.e. larger volume), the factor of safety drops more. Also, the recovery of factor of safety does not seem to depend on the rainfall loading; it seems to depend on the slope geometry instead.

More examples with different slope geometry and soil properties should be explored in the future. In addition, a more realistic rainfall with varying intensity or antecedent rainfall may be applied to further the understanding of the effect of rainfall to slope stability.

\section{ACKNOWLEDGEMENT}

The author would like to show his gratitude to his supervisor, Professor Harianto Rahardjo for his guidance and support throughout this paper. His kind advice and patience 
will not be forgotten by the author. The author would also like to thank the project officers, Henry Krisdani for his assistance and counsel, as well as the Geotechnics laboratory and CADD laboratory staff for the technical support provided.

\section{REFERENCES}

1. Fourie, A. B., (1996), Predicting rainfall-induced slope instability, Proc. Institution of Civil Engineers and Geotechnical Engineering, vol. 119, pp. 211-218, October 1996.

2. Lumb, P., (1975), Slope failures in Hong Kong, Quarterly J. Engineering Geology. Vol 8, pp. 31-65.

3. Rahardjo, H., (2000), Rainfall-induced slope failures, Researh Report: NSTB 17/6/16, Nanyang Technological University.

4. Rahardjo, H., Ong, T.H., Rezaur, R.B., Leong, E.C., (2006), Factors Controlling Instability of Homogeneous Soil Slopes Under Rainfall Loading, in press.

5. Chong, K.L., (2007), Shear Strength Characteristics of Granitic Bukit Timah Formation, unpublished.

6. Khonesavanh V., (2007), Relationship between Shear Strength Properties and Soil Water Characteristic Curve, unpublished. 